ISSN 0258-7122

Bangladesh J. Agril. Res. 40(4): 591-600, December 2015

\title{
EFFECT OF PLANT GROWTH REGULATORS ON FLOWER AND BULB PRODUCTION OF HIPPEASTRUM (Hippeastrum hybridum Hort.)
}

\author{
M. K. JAMIL ${ }^{1}$, M. MIZANUR RAHMAN ${ }^{2}$, M. MOFAZZAL HOSSAIN ${ }^{3}$ \\ M. TOFAZZAL HOSSAIN ${ }^{4}$, AND A. J. M. SIRAJUL KARIM ${ }^{5}$
}

\begin{abstract}
The experiment was conducted at the Horticultural research field of Bangabandhu Sheikh Mujibur Rahman Agricultural University, Salna, Gazipur during October 2008 to July 2009 to investigate the effect of plant growth regulators on flower and bulb production of Hippeastrum. There were ten treatments comprising of three concentrations of three growth regulators viz., IAA (20, 60 and $100 \mathrm{ppm})$, ethrel (100, 300 and $500 \mathrm{ppm})$ and $\mathrm{GA}_{3}(100,300$ and $500 \mathrm{ppm}$ ) along with control (soaked in water). The experiment was laid out in a Randomized Complete Block Design (RCBD) with three replications. Flower and bulb characteristics of Hippeastrum were influenced significantly by different levels of growth regulators. Application of IAA at 60 and $100 \mathrm{ppm}$ and $\mathrm{GA}_{3}$ at 100,300 or $500 \mathrm{ppm}$ twice as foliar spray at an interval of 30 days promoted the number of bulblets on the treated plants. Ethrel at a concentration of $100 \mathrm{ppm}$ increased the number of flowers per scape (4) and showed earliness in days to flower scape emergence (72.33 days) and first flower open (88.67 days). On the other hand, the biggest size of flower $(15.14 \mathrm{~cm} \mathrm{x} 12.44 \mathrm{~cm})$ and flower scape $(40.28 \mathrm{~cm} \times 21.95 \mathrm{~cm})$ at harvest and the maximum days for flowering (11.50 days) were evident from plants treated with $500 \mathrm{ppm} \mathrm{GA}_{3}$. The highest number of bulblets per plot (40.00), bulbs weight per plot (4056 g) along with bulb yield (40.56 t/ha) were also obtained in $\mathrm{GA}_{3}$ at $500 \mathrm{ppm}$.
\end{abstract}

Keywords: Hippeastrum, indole-acetic acid (IAA), 2-chloroethylphosphonic acid (Ethrel), gibberrellic acid $\left(\mathrm{GA}_{3}\right)$, Hippeastrum flower and bulb yield.

\section{Introduction}

Hippeastrum (Hippeastrum hybridum Hort.) is an important ornamental bulbous plant used as cut flowers because of their large size, attractive colour, and good keeping quality. In Bangladesh, the agro-ecological conditions are very conducive for the survival and culture of Hippeastrum. It has great potential for local as well as export market.

Ornamental crops like Hippeastrum find extensive use of growth regulators for modifying their developmental processes. The major areas where growth regulators have successfully played their roles in ornamental plants are in vegetative propagation, inhibition of abscission, prevention of bud dormancy,

${ }^{1}$ Senior Scientific Officer, Biotechnology Division, Bangladesh Agricultural Research Institute (BARI), Gazipur, ${ }^{2 \& 3}$ Professor, Department of Horticulture, Bangabandhu Sheikh Mujibur Rahman Agricultural University (BSMRAU), ${ }^{4}$ Professor, Department of Crop Botany, BSMRAU, ${ }^{5}$ Professor, Department of Soil Science, BSMRAU, Salna, Gazipur, Bangladesh. 
growth control, promotion of flowering, prolonging the vase life of flowers and retarding their senescence (Murti and Upreti, 1995).

Growth and flowering of Hippeastrum is influenced by several factors. Among the various external factors, growth regulators play an important role in developmental process of the plants. There are only a few floricultural crops on which growth regulators were applied for the purpose of enhancing growth. The gibberrelic acid $\left(\mathrm{GA}_{3}\right)$ has been of considerable use for growth promotion. The cases in which growth promotion by growth regulators would be helpful are those where environmental factors delay or inhibit growth or where problems are encountered due to excessive application of retardants.

Application of growth regulators was found to improve the growth and flowering of Hippeastrum. Bhattacharjee (1983a) reported that treatment with $\mathrm{GA}_{3}$ at 10 ppm markedly improved the flower production of lily (Lilium tigrinum, KerGawl). Naphthalene acetic acid (NAA) at $100 \mathrm{ppm}$ and $\mathrm{GA}_{3}$ at 100 or $200 \mathrm{ppm}$ induced early flowering in Lilium longiflorum whereas NAA at $200 \mathrm{ppm}$ and $\mathrm{GA}_{3}$ at $200 \mathrm{ppm}$ markedly increased flower production as reported by Pal and Das (1990). In an experiment with growth regulators on Asiatic hybrid lily, Dantuluri et al. (2002) found that $\mathrm{GA}_{3}$ at $200 \mathrm{ppm}$ produced the tallest plants and $\mathrm{GA}_{3}$ at $200 \mathrm{ppm}$ exhibited earliest bud formation and flowering. Spraying with 2chloro ethylphosphonic acid (ethrel) at 1000-4000 ppm, 1-3 times has been found to hasten the flower induction in Golden Shower Oncidium (Bose et al., 1999).

Soaking of Hippeastrum bulbs in three concentrations each of Indole acetic acid (IAA), $\mathrm{GA}_{3}$, Chlorocholine chloride (CCC) and ethrel showed various responses on growth and flowering. IAA increased the weight and number of bulblets while $\mathrm{GA}_{3}$ enhanced the flower diameter and bulb weight. Application of IAA at 100 ppm and $\mathrm{GA}_{3}$ at 10,100 or $1000 \mathrm{ppm}$ twice as foliar spray at an interval of 15 days promoted the number of bulbs on the treated plants while ethrel increased the weight of bulblets. All concentrations of IAA and $\mathrm{GA}_{3}$ increased the number and size of flowers as reported by Bose et al. (1980). Bhattacharjee (1983b) concluded that ethrel had beneficial effect on bulb formation. Application of IAA and $\mathrm{GA}_{3}$ each at 10 to $1000 \mathrm{ppm}$ also promoted vegetative growth, induced early flowering, increased flower size and stalk length, enhanced the number of flower per stalk, extended flower longevity, improved number, size and weight of bulb. Information regarding the use of plant growth regulators on flower and bulb production of Hippeastrum in Bangladesh is very scanty. Keeping these views in mind, the present investigation was undertaken to study the effect of IAA, ethrel and $\mathrm{GA}_{3}$ on flower and bulb production of Hippeastrum.

\section{Materials and Method}

The experiment was carried out at the Horticultural research farm of Bangabandhu Sheikh Mujibur Rahman Agricultural University, Salna, Gazipur during October 2008 to July 2009. The experiment was laid out in a Randomized Complete Block Design (RCBD) having ten concentrations of growth regulators viz., $\mathrm{T}_{1}=20 \mathrm{ppm}$ 
IAA, $T_{2}=60 \mathrm{ppm}$ IAA, $\mathrm{T}_{3}=100 \mathrm{ppm}$ IAA, $\mathrm{T}_{4}=100 \mathrm{ppm}$ ethrel, $\mathrm{T}_{5}=300 \mathrm{ppm}$ ethrel, $\mathrm{T}_{6}=500 \mathrm{ppm}$ ethrel, $\mathrm{T}_{7}=100 \mathrm{ppm} \mathrm{GA}, \mathrm{T}_{8}=300 \mathrm{ppm} \mathrm{GA}, \mathrm{T}_{9}=500 \mathrm{ppm}$ $\mathrm{GA}_{3}$ and $\mathrm{T}_{10}=$ Control (soaked in water) with three replications. The experimental field was first disc-ploughed and harrowed. Final land preparation was done by a power tiller followed by leveling with scrapper. Clods were broken and weeds were removed from the field to obtain desirable tilth. Irrigation and drainage channels were made around the block. There were $30(10 \times 3)$ unit plots; each measuring $1 \mathrm{~m} \times 1.5 \mathrm{~m}$ with $15 \mathrm{~cm}$ raised bed to prevent the bulbs from fungal disease caused by water logging. The plots were separated from one another by 1 $\mathrm{m}$ spaces. Bulb to bulb distance $25 \mathrm{~cm}$ and row to row distance $50 \mathrm{~cm}$ were maintained which constituted 12 plants per plot. Total $360(30 \times 12)$ bulbs were used for different treatments in the experiment. Uniform sized $(5 \mathrm{~cm}$ in diameter) bulbs were collected from the field and kept two weeks for curing. Curing is a drying process intended to dry off the necks and outer scale leaves of the bulbs to prevent the loss of moisture and the attack by decay during storage. After harvesting when the bulbs were matured as indicated by yellowing and drying of leaves, the bulbs were dug out and tops were cut down. Then the bulbs were stored in trays and kept in a cool room $\left(13^{\circ} \mathrm{C}\right)$. Selected bulbs were cleaned carefully by removing the roots, leaves and dry scales by using a sharp knife which was sterilized to avoid spread of diseases. Selected bulbs were soaked for 24 hours in different concentrations of IAA, ethrel and $\mathrm{GA}_{3}$ solution and also in water as per the treatment schedule. After soaking, the treated bulbs were wrapped in tissue paper and immediately planted in the field. The crop was fertilized with Cow dung $=10 \mathrm{t} / \mathrm{ha}$, Urea $=200 \mathrm{~kg} / \mathrm{ha}, \mathrm{TSP}=400 \mathrm{~kg} / \mathrm{ha}$ and MP $=200 \mathrm{~kg} / \mathrm{ha}$ (Jana and Bose, 1980). Total amount of cow dung, TSP and MP were applied at the time of final land preparation. Urea $200 \mathrm{~kg} / \mathrm{ha}$ was applied in two equal installments of 30 and 60 days after emergence which was followed by irrigation. Cultural operations such as irrigating the crop at different growth stages, weeding and pest and disease control measures were taken as and when necessary. The scape of the flower was cut when the buds were fully elongated. Harvesting of scape was done early in the morning and the stalks were placed in water. Diameter of mother bulb and bulblets were measured after curing of bulb. Necessary data on different characters were recorded and analyzed statistically using MSTAT- C program to find out the variation among the treatments by F-test. Treatment means were compared by Duncan's Multiple Range Test (DMRT) for interpretation of results (Gomez and Gomez, 1984).

\section{Results and Discussion}

The results obtained in the study have been described and discussed along with tables and figures.

\section{Days to first flower scape emergence}

Days to flower scape emergence of Hippeastrum was significantly influenced by different growth regulators (Table 1). From the table it can be revealed that first 
flower scape emergence ( 72.33 days) commenced the earliest with ethrel at 100 ppm while late (93.67 days) in plants with control. This is in agreement with the findings of Bose et al. (1999) who reported that spraying with ethrel at 1000$4000 \mathrm{ppm}, 1-3$ times at intervals, has been found to hasten the flower induction in Golden Shower Oncidium. In this connection a little bit different results were found by Dhiman (1997) where earlier flowering in Lilium hybrids (115.50 and 120.20 days) was observed with $\mathrm{GA}_{3}$ at $100 \mathrm{ppm}$. Pal and Das (1990) also reported that NAA $(100 \mathrm{ppm})$ and $\mathrm{GA}_{3}(100$ or $200 \mathrm{ppm})$ induced early flowering in Lilium longiflorum.

\section{Days to first flower open}

Different growth regulators was found to influence significantly the days to first flower open of Hippeastrum (Table 1). It can be revealed that days to first flower open was the earliest (88.67 days) in plants treated with ethrel at $100 \mathrm{ppm}$ which was closely followed by ethrel at $300 \mathrm{ppm}$. The control plants took the longest period (113.40 days) for first flower open. This result is supported by Bose et al. (1999) who reported that spraying with ethrel at 1000-4000 ppm, 1-3 times at intervals, hastened the flower induction in Golden Shower Oncidium.

\section{Flower scape per plant}

Flower scape per plant of Hippeastrum was counted at the time of flower scape harvest. Significant variation was not found in flower scape per plant due to different growth regulators (Table 1). However, the highest flower scape per plant (2.00) was produced in ethrel at $500 \mathrm{ppm}$ treated plant and the lowest (1.00) in control and IAA at $20 \mathrm{ppm}$.

\section{Flowers per scape}

The effect of different growth regulators showed significant influence on flowers per scape of Hippeastrum (Table 1). The maximum flowers per scape (4.00) was recorded in plants treated with ethrel at $100 \mathrm{ppm}$ and the control plants produced the minimum (2.44). The result is in agreement with the report of Sujatha et al. (2002) and Karaguzel et al. (1999) who stated that the number of flowers per plant increased with different growth regulators. Similar trend in flowers per scape of Hippeastrum was also reported by Bose et al. (1980).

\section{Length of flower}

Length of flower of Hippeastrum was significantly influenced by different growth regulators (Fig. 1). However, the highest length of flower $(15.14 \mathrm{~cm})$ was recorded from plants treated with $\mathrm{GA}_{3}$ at $500 \mathrm{ppm}$. The lowest value for flower length $(12.24 \mathrm{~cm})$ was noted in control. This might be due to the fact that $\mathrm{GA}_{3}$ treated plant produced more number of leaves compared to control and other treatments, which might have resulted in production and accumulation of more photosynthates that were diverted to flowers resulting in longer and larger size flower. The findings are in agreement with those of Pal and Choudhury (1998) 
who found that $\mathrm{GA}_{3}$ at $100 \mathrm{ppm}$ significantly increased leaf area, induced early appearance of flower spike, highest number of florets/spike and largest individual florets in gladiolus cv. Hunting Song. Prakash and Jha (1998) also observed that application of $\mathrm{GA}_{3}$ at $150 \mathrm{ppm}$ improved all the floral traits (time of flowering, inflorescence length, spike length, floret length and number of florets/spike) in gladiolus, cv. Friendship.

Table 1. Effect of plant growth regulators on flowering characteristics of Hippeastrum.

\begin{tabular}{|c|c|c|c|c|}
\hline Treatment & $\begin{array}{c}\text { Days to flower } \\
\text { scape emergence }\end{array}$ & $\begin{array}{l}\text { Days to first } \\
\text { flower open }\end{array}$ & $\begin{array}{c}\text { Flower scape } \\
\text { per plant }\end{array}$ & $\begin{array}{c}\text { Flowers per } \\
\text { scape }\end{array}$ \\
\hline \multicolumn{5}{|l|}{ IAA } \\
\hline $20 \mathrm{ppm}\left(\mathrm{T}_{1}\right)$ & $91.00 \mathrm{ab}$ & $109.6 \mathrm{~b}$ & 1.00 & $3.06 \mathrm{bc}$ \\
\hline $60 \mathrm{ppm}\left(\mathrm{T}_{2}\right)$ & $90.00 \mathrm{ab}$ & $105.9 \mathrm{c}$ & 1.06 & $3.42 \mathrm{ab}$ \\
\hline $100 \mathrm{ppm}\left(\mathrm{T}_{3}\right)$ & $88.67 \mathrm{bc}$ & $104.3 \mathrm{c}$ & 1.17 & $3.39 \mathrm{ab}$ \\
\hline \multicolumn{5}{|l|}{ Ethrel } \\
\hline $100 \mathrm{ppm}\left(\mathrm{T}_{4}\right)$ & $72.33 \mathrm{e}$ & $88.67 \mathrm{~h}$ & 1.11 & $4.00 \mathrm{a}$ \\
\hline $300 \mathrm{ppm}\left(\mathrm{T}_{5}\right)$ & $84.33 \mathrm{~d}$ & $92.28 \mathrm{~g}$ & 1.22 & $3.28 \mathrm{ab}$ \\
\hline $500 \mathrm{ppm}\left(\mathrm{T}_{6}\right)$ & $85.33 \mathrm{~cd}$ & $95.83 \mathrm{f}$ & 2.00 & $3.06 \mathrm{bc}$ \\
\hline \multicolumn{5}{|l|}{$\mathrm{GA}_{3}$} \\
\hline $100 \mathrm{ppm}\left(\mathrm{T}_{7}\right)$ & $93.33 \mathrm{a}$ & $102.1 \mathrm{~d}$ & 1.28 & $3.45 \mathrm{ab}$ \\
\hline $300 \mathrm{ppm}\left(\mathrm{T}_{8}\right)$ & $92.67 \mathrm{ab}$ & $99.22 \mathrm{e}$ & 1.28 & $3.45 \mathrm{ab}$ \\
\hline 500 ppm $\left(\mathrm{T}_{9}\right)$ & $91.00 \mathrm{ab}$ & $95.11 \mathrm{f}$ & 1.28 & $3.72 \mathrm{ab}$ \\
\hline Control $\left(\mathrm{T}_{10}\right)$ & $93.67 \mathrm{a}$ & $113.4 \mathrm{a}$ & 1.00 & $2.44 \mathrm{c}$ \\
\hline Level of significance & $* *$ & $* *$ & $\mathrm{~ns}$ & $* *$ \\
\hline $\mathrm{CV}(\%)$ & 2.34 & 1.52 & 11.98 & 6.22 \\
\hline
\end{tabular}

Means having same letter(s) in a column are not significantly different by DMRT. indicates significant at $1 \%$ level.

\section{Diameter of flower}

A significant variation in the diameter of flower of Hippeastrum was observed due to the effect of different growth regulators (Fig. 1). $\mathrm{GA}_{3}$ at $500 \mathrm{ppm}$ showed the maximum diameter of flower $(12.44 \mathrm{~cm})$ which was statistically similar with that of plants treated with ethrel at $500 \mathrm{ppm}$ and the control plants produced the narrowest flower $(10.89 \mathrm{~cm})$. This might be due to the fact that $\mathrm{GA}_{3}$ treated plant produced more food that was diverted to only a fewer sink and hence bigger flowers were produced. Similar result is reported by Bose et al. (1980) who studied the effect of growth regulators on the growth and flowering in Hippeastrum. Sujatha et al. (2002) found that foliar application of $100 \mathrm{ppm} \mathrm{GA}$ at monthly interval from January to May was the best for obtaining best growth of plants, maximum number of cut blooms with stalk length as well as flower size in gerbera. 


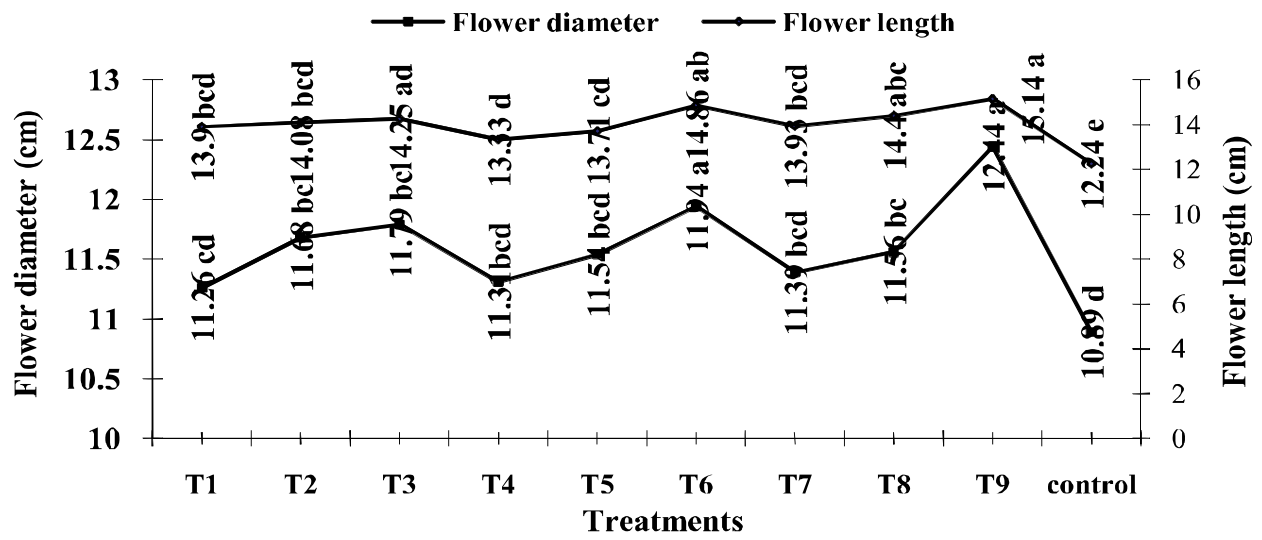

Fig. 1. Effect of growth regulators on flower length and diameter of Hippeastrum.

$$
\begin{array}{lcl}
\mathrm{T}_{1}=20 \mathrm{ppm} \mathrm{IAA} & \mathrm{T}_{4}=100 \mathrm{ppm} \text { Ethrel } & \mathrm{T}_{7}=100 \mathrm{ppm} \mathrm{GA} \\
\mathrm{T}_{2}=60 \mathrm{ppm} \mathrm{IAA} & \mathrm{T}_{5}=300 \mathrm{ppm} \text { Ethrel } & \mathrm{T}_{8}=300 \mathrm{ppm} \mathrm{GA} \mathrm{GA}_{3} \\
\mathrm{~T}_{3}=100 \mathrm{ppm} \text { IAA } & \mathrm{T}_{6}=500 \mathrm{ppm} \text { Ethrel } & \mathrm{T}_{9}=500 \mathrm{ppm} \mathrm{GA}_{3} \text { and } \\
\mathrm{T}_{10}=\text { Control (soaked in water) } &
\end{array}
$$

\section{Flower scape length}

Flower scape length of Hippeastrum was measured at the time of harvest. It was observed that flower scape length was significantly influenced by different growth regulators (Fig. 2). The longest flower scape $(40.28 \mathrm{~cm})$ was recorded from $\mathrm{GA}_{3}$ at $500 \mathrm{ppm}$ and the shortest $(29.60 \mathrm{~cm})$ was produced by control plants. This might be due to the fact that gibberrellic acids promote cell division and cell enlargement which ultimately resulted in longer flower scape. Similar results were reported by Karaguzel et al. (1999), Pal and Choudhury (1998) in gladiolus at 100 ppm GA 3 , and Prakash and Jha (1998) in gladiolus at $150 \mathrm{ppm}$ $\mathrm{GA}_{3}$.

\section{Flower scape diameter}

Different growth regulators exhibited significant variation on flower scape diameter of Hippeastrum (Fig. 2). The maximum value for flower scape diameter $(21.95 \mathrm{~cm})$ was obtained from plants treated with $\mathrm{GA}_{3}$ at $500 \mathrm{ppm}$ and the minimum $(17.09 \mathrm{~cm})$ from control plants. This might be due to that the highest concentration of $\mathrm{GA}_{3}$ enhanced plant growth which increased the diameter of flower scape. This is in line with the findings of Karaguzel et al. (1999) in gladiolus. They found that soaking of corms at $100 \mathrm{ppm} \mathrm{GA}_{3}$ for one hour increased the length of flower stem and spikes, the number of flowers per spike and the diameter of flower stem. 


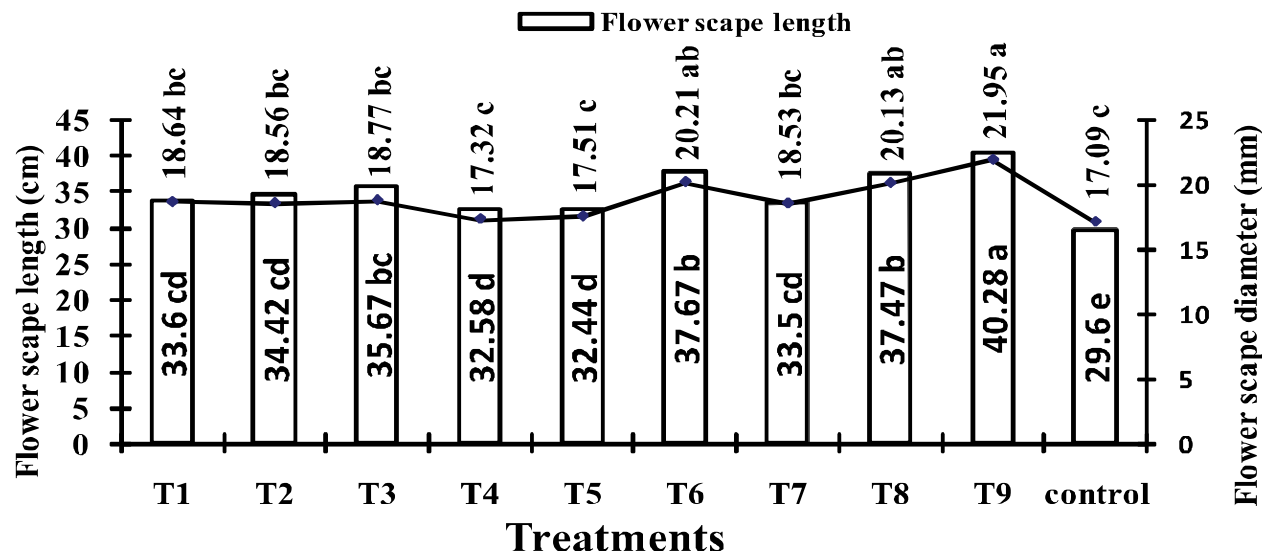

Fig. 2. Effect of growth regulators on flower scape length and diameter of Hippeastrum at harvest.

$\begin{array}{lrl}\mathrm{T}_{1}=20 \mathrm{ppm} \text { IAA } & \mathrm{T}_{4}=100 \mathrm{ppm} \text { Ethrel } & \mathrm{T}_{7}=100 \mathrm{ppm} \mathrm{GA}_{3} \\ \mathrm{~T}_{2}=60 \mathrm{ppm} \mathrm{IAA} & \mathrm{T}_{5}=300 \mathrm{ppm} \text { Ethrel } & \mathrm{T}_{8}=300 \mathrm{ppm} \mathrm{GA} \mathrm{GA}_{3} \\ \mathrm{~T}_{3}=100 \mathrm{ppm} \text { IAA } & \mathrm{T}_{6}=500 \mathrm{ppm} \text { Ethrel } & \mathrm{T}_{9}=500 \mathrm{ppm} \mathrm{GA}_{3} \text { and } \\ \mathrm{T}_{10}=\text { Control (soaked in water) } & \end{array}$

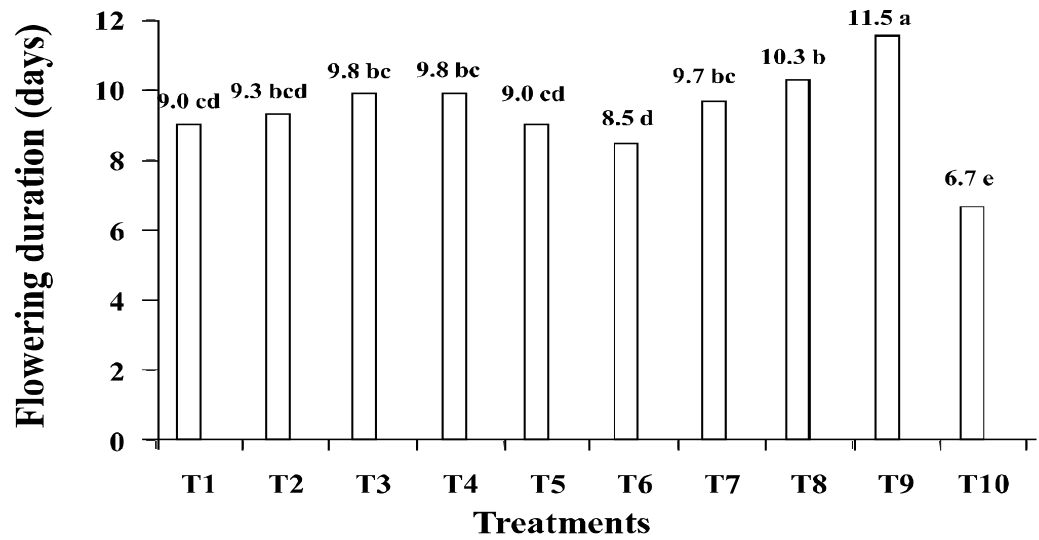

Fig. 3. Effect of growth regulators on flowering duration of Hippeastrum.

$$
\begin{array}{lrl}
\mathrm{T}_{1}=20 \mathrm{ppm} \text { IAA } & \mathrm{T}_{4}=100 \mathrm{ppm} \text { Ethrel } & \mathrm{T}_{7}=100 \mathrm{ppm} \mathrm{GA}_{3} \\
\mathrm{~T}_{2}=60 \mathrm{ppm} \mathrm{IAA} & \mathrm{T}_{5}=300 \mathrm{ppm} \text { Ethrel } & \mathrm{T}_{8}=300 \mathrm{ppm} \mathrm{GA} \mathrm{GA}_{3} \\
\mathrm{~T}_{3}=100 \mathrm{ppm} \mathrm{IAA} & \mathrm{T}_{6}=500 \mathrm{ppm} \text { Ethrel } & \mathrm{T}_{9}=500 \mathrm{ppm} \mathrm{GA}_{3} \text { and } \\
\mathrm{T}_{10}=\text { Control (soaked in water) } &
\end{array}
$$

\section{Flowering duration}

Significant influence was observed on flowering duration of Hippeastrum by different growth regulators (Fig. 3). The maximum duration of flowering (11.50 days) was observed in $\mathrm{T}_{9}$ (i.e. 500 ppm $\mathrm{GA}_{3}$ ) while the minimum (6.70 days) was in control. The increased flowering duration could be attributed to the higher root 
development by $\mathrm{GA}_{3}$ and increased the efficiency of manufacturing carbohydrate which maintained the freshness of flower for longer time. Similar findings were reported by Verma et al. (1995) that a single foliar spray of $\mathrm{GA}_{3}$ (100 and 200 ppm) in chrysanthemum enhanced vegetative growth and flowering. Application of $40 \mathrm{ppm} \mathrm{GA}_{3}$ produced spikes having the longest (16.20 days) life in the field (Pal and Chowdhury, 1998).

\section{Bulblets per plot}

Number of bulblets per plot of Hippeastrum was counted after digging out of bulb. It was observed that different growth regulators significantly influenced the bulblets per plot (Table 2). The maximum number of bulblets per plot (40.00) was obtained from $\mathrm{GA}_{3}$ at $500 \mathrm{ppm}$ and the minimum (24.00) from control. This result is in full agreement with that of Bose et al. (1980). They reported that $\mathrm{GA}_{3}$ at 10,100 or $1000 \mathrm{mg} \mathrm{l}^{-1}$ twice as foliar spray at an interval of 30 days promoted the number of bulblets of the treated plants.

Table 2. Effect of plant growth regulators on bulb characteristics of Hippeastrum.

\begin{tabular}{|c|c|c|c|c|}
\hline \multirow{2}{*}{ Treatment } & \multirow{2}{*}{ Bulblets/plot } & \multicolumn{2}{|c|}{ Bulb diameter (mm) } & \multirow{2}{*}{$\begin{array}{l}\text { Bulb yield/plot } \\
(\mathrm{g})\end{array}$} \\
\hline & & Mother bulb & Bulblets & \\
\hline \multicolumn{5}{|l|}{ IAA } \\
\hline $20 \mathrm{ppm}\left(\mathrm{T}_{1}\right)$ & $30.67 \mathrm{~cd}$ & 68.14 b-e & 28.67 bcd & $3091 \mathrm{f}$ \\
\hline $60 \mathrm{ppm}\left(\mathrm{T}_{2}\right)$ & $36.00 \mathrm{abc}$ & 70.17 a-d & $30.27 \mathrm{ab}$ & $3138 \mathrm{e}$ \\
\hline $100 \mathrm{ppm}\left(\mathrm{T}_{3}\right)$ & $38.67 \mathrm{ab}$ & $72.63 \mathrm{ab}$ & $32.48 \mathrm{a}$ & $3458 \mathrm{~d}$ \\
\hline \multicolumn{5}{|l|}{ Ethrel } \\
\hline $100 \mathrm{ppm}\left(\mathrm{T}_{4}\right)$ & $29.33 \mathrm{~cd}$ & 64.19 ef & $26.35 \mathrm{~cd}$ & $2879 \mathrm{~h}$ \\
\hline $300 \mathrm{ppm}\left(\mathrm{T}_{5}\right)$ & $30.67 \mathrm{~cd}$ & 65.14 def & $27.35 \mathrm{bcd}$ & $2898 \mathrm{~g}$ \\
\hline $500 \mathrm{ppm}\left(\mathrm{T}_{6}\right)$ & $32.00 \mathrm{bc}$ & $66.75 \mathrm{c}-\mathrm{f}$ & 28.35 bcd & $2902 \mathrm{~g}$ \\
\hline \multicolumn{5}{|l|}{$\mathrm{GA}_{3}$} \\
\hline $100 \mathrm{ppm}\left(\mathrm{T}_{7}\right)$ & $34.67 \mathrm{abc}$ & $70.64 \mathrm{abc}$ & $29.71 \mathrm{abc}$ & $3615 \mathrm{c}$ \\
\hline $300 \mathrm{ppm}\left(\mathrm{T}_{8}\right)$ & $38.67 \mathrm{ab}$ & $72.34 \mathrm{ab}$ & $32.39 \mathrm{a}$ & $3927 \quad b$ \\
\hline $500 \mathrm{ppm}\left(\mathrm{T}_{9}\right)$ & $40.00 \mathrm{a}$ & $75.49 \mathrm{a}$ & $32.99 \mathrm{a}$ & $4056 \mathrm{a}$ \\
\hline Control $\left(\mathrm{T}_{10}\right)$ & $24.00 \mathrm{~d}$ & $62.17 \mathrm{f}$ & $25.21 \mathrm{~d}$ & $2639 \mathrm{i}$ \\
\hline Level of significance & $* *$ & $* *$ & $* *$ & $* *$ \\
\hline $\mathrm{CV} \%$ & 7.52 & 2.72 & 4.22 & 16.35 \\
\hline
\end{tabular}

Means having same letter(s) and without letters in a column are not significant by DMRT. ** indicates significant at $1 \%$ level.

\section{Bulb diameter}

Highly significant variation in diameter of bulb due to different growth regulators was found in this study (Table 2). However, the highest value for bulb diameter $(75.49 \mathrm{~mm})$ in case of mother bulb was recorded from $\mathrm{GA}_{3}$ at $500 \mathrm{ppm}$ and the lowest $(62.17 \mathrm{~mm})$ was found in control. Similar trend was also found in case of bulblets diameter. Gibberellin might accelerated cell division and cell elongation which lead to increased elongation of root (Stewart and Jones, 1977). Thus, it 
enhanced the diameter of bulbs. The results are in partial agreement with Biswas et al. (1982) who reported that $\mathrm{GA}_{3}$ at $100 \mathrm{ppm}$ produced the highest diameter of bulb in tuberose.

\section{Bulb yield per plot}

The effect of different growth regulators on bulb yield per plot was found significant (Table 2). The maximum bulb yield (4056 g) was obtained from $\mathrm{GA}_{3}$ at $500 \mathrm{ppm}$ and the minimum $(2639 \mathrm{~g})$ from control. This may be due to that $\mathrm{GA}_{3}$ enhanced better growth of bulbs and consequently produced the higher bulb yield per plot. These results are in conformity with the findings reported by Umrao et al. (2007) where they found increased weight of corm for treating with $\mathrm{GA}_{3}$. A similar result was also reported by Bose et al. (1980) in Hippeastrum.

\section{Bulb yield per hectare}

Bulb yield per hectare of Hippeastrum varied significantly due to the influence of different growth regulators (Fig. 4). From the figure it can be revealed that the highest bulb yield ( $40.56 \mathrm{t} / \mathrm{ha}$ ) was recorded in $\mathrm{T}_{9}$ while the lowest $(26.39 \mathrm{t} / \mathrm{ha})$ in control. This finding is in full agreement with that of Bose et al. (1980) who reported that $\mathrm{GA}_{3}$ enhanced the flower diameter and bulb yield of Hippeastrum.

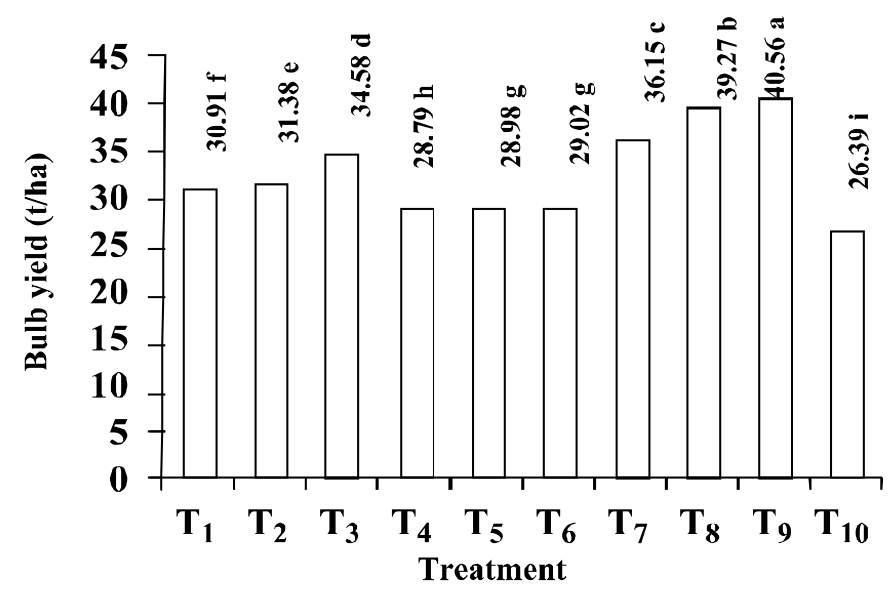

Fig. 4. Effect of growth regulators on bulbs yield (t/ha) of Hippeastrum.

$$
\begin{array}{lrl}
\mathrm{T}_{1}=20 \mathrm{ppm} \mathrm{IAA} & \mathrm{T}_{4}=100 \mathrm{ppm} \text { Ethrel } & \mathrm{T}_{7}=100 \mathrm{ppm} \mathrm{GA}_{3} \\
\mathrm{~T}_{2}=60 \mathrm{ppm} \mathrm{IAA} & \mathrm{T}_{5}=300 \mathrm{ppm} \mathrm{Ethrel} & \mathrm{T}_{8}=300 \mathrm{ppm} \mathrm{GA} \mathrm{GA}_{3} \\
\mathrm{~T}_{3}=100 \mathrm{ppm} \mathrm{IAA} & \mathrm{T}_{6}=500 \mathrm{ppm} \mathrm{Ethrel} & \mathrm{T}_{9}=500 \mathrm{ppm} \mathrm{GA}_{3} \text { and } \\
\mathrm{T}_{10}=\text { Control (soaked in water) } &
\end{array}
$$

\section{Conclusion}

Based on the above discussion, it can be concluded that the plant growth regulators has significant effect on flower and bulb production of Hippeastrum. Bulbs treated with ethrel at $100 \mathrm{ppm}$ enhanced early emergence of flower scape and flowering, maximum flowers per scape while $\mathrm{GA}_{3}$ at $500 \mathrm{ppm}$ performed 
better for bigger size flower and flower scape, flowering duration and bulb production of Hippeastrum.

\section{References:}

Bhattacharjee, S.K. 1983(a). Response of Lilium tigrinum Ker-Gawl (tiger lily) to soil drench application of growth regulating chemicals. Progressive Agriculture. 15: 204-209.

Bhattacharjee, S.K. 1983(b). Influence of growth regulating chemicals on Hippeastrum hybridum Hort. Gardens Bulletin, Singapore. 30: 237-240.

Biswas, J., T.K. Bose and R.G. Matti. 1982. Effect of growth substances on growth and flowering of tuberose (Polianthes tuberose Lin.). South Indian Hort. 31(2): 129-132.

Bose,T.K., B.K. Jana, and T.P. Mukhopadhyay. 1980. Effect of growth regulators on growth and flowering of Hippeastrum hybridum. Scientia Horticulturae. 12: 195-200.

Bose,T.K., R.G. Maiti, R.S. Dhua and P. Das. 1999. Gerbera. Floriculture and Landscaping. Ist ed. Nayaprokash, Calcutta, India. pp. 530-537.

Dantuluri, V.S.R., R.L. Misra (ed.), Sanyat-Misra. 2002. Effect of growth regulating chemicals on Asiatic hybrid lily. Floriculture research trend in India. Proceedings of the national symposium on Indian floriculture in the new millennium, Lal-Bagh, Bangalore, 25-27 February, 2002. 147-149.

Dhiman, M.R. 1997. Effect of cold storage temperature and plant bio-regulators on growth and flower production in Lilium hybrids. M.Sc. thesis, Department of Floriculture and Landscape Architecture. Dr. Yashwant Singh Parmar University of Horticulture \& Forestry, Nauni, Solan, India, pp. 20-55.

Gomez, K.A. and A.A. Gomez. 1984. Statistical Procedures for Agricultural Research $\left(2^{\text {nd }}\right.$ edition). Int. Rice Res. Inst. John Wiley and Sons publication, New York. pp. 28-192.

Jana, B.K. and T.K. Bose. 1980. Effect of fertilizers on growth and flowering of Hippeastrum. Indian Agric. 24: 23-30.

Karaguzel, O., S. Alian., I. Doran and Z. Sogut. 1999. Improvement of gladiolus by growth regulator and nutrient management. J. Japanese Soc. Hort. Sci. 68: 168-175.

Murti, G.S.R. and K.K. Upreti, 1995. Advances in Horticulture - Ornamental Plants. In: Use of growth regulators in ornamental plants. Eds. K.L.Chadha and S.K. Bhattacharjee. Malhotra Publishing House, New Delhi-110064, India. 12: 863.

Pal, A.K. and S.N. Das, 1990. Effect of growth regulators on growth and flowering of Lilium longiflorum. Orissa J. Horticulture. 18: 18-21.

Pal, P. and T. Chowdhury. 1998. Elongation of flowering by GA 3 . Hort. J. 11: 69-77.

Prakash, V. and K.K. Jha. 1998. Physiology of gladiolus. J. Applied Biol. 8: 24-28.

Stewart, D.A. and R.I. Jones. 1977. The role of extensibility and turgor in gibberellins and dark stimulated growth. Plant Physiology. 59: 61-68.

Sujatha, A., I. Nair, V. Singh and T.V.R.S. Sharma. 2002. Effect of plant growth regulators on yield and quality of gerbera under Bay Island conditions. Indian J. Hort. 59 (1): 100-105.

Umrao, Vijai. K., R.P. Singh and A.R.Singh. 2007. Effect of gibberellic acid and growing media on vegetative and floral attributes of gladiolus. Indian J. Hort. 64 (1): 73-76.

Verma, S.C., M.M. Haider, M.A. Kher and A.S. Murty. 1995. A note on the influence of gibberellic acid $\left(\mathrm{GA}_{3}\right)$ and ascorbic acid on stem length and blooming in chrysanthemum cv. Cotton Ball. J. Ornamental Hort. 3 (1-3): 30-31. 